\title{
Dual electrically and thermally responsive broadband reflectors based on polymer network stabilized chiral nematic liquid crystals: the role of crosslink density
}

\author{
Citation for published version (APA): \\ Khandelwal, H., Timmermans, G. H., Debije, M. G., \& Schenning, A. P. H. J. (2016). Dual electrically and \\ thermally responsive broadband reflectors based on polymer network stabilized chiral nematic liquid crystals: the \\ role of crosslink density. Chemical Communications, ChemComm, 52(66), 10109-10112. \\ https://doi.org/10.1039/C6CC04721A
}

\section{Document license: \\ TAVERNE}

DOI:

10.1039/C6CC04721A

Document status and date:

Published: 01/01/2016

\section{Document Version:}

Publisher's PDF, also known as Version of Record (includes final page, issue and volume numbers)

\section{Please check the document version of this publication:}

- A submitted manuscript is the version of the article upon submission and before peer-review. There can be important differences between the submitted version and the official published version of record. People interested in the research are advised to contact the author for the final version of the publication, or visit the DOI to the publisher's website.

- The final author version and the galley proof are versions of the publication after peer review.

- The final published version features the final layout of the paper including the volume, issue and page numbers.

Link to publication

\footnotetext{
General rights

- You may freely distribute the URL identifying the publication in the public portal. follow below link for the End User Agreement:

www.tue.nl/taverne

\section{Take down policy}

If you believe that this document breaches copyright please contact us at:

openaccess@tue.nl

providing details and we will investigate your claim.
}

Copyright and moral rights for the publications made accessible in the public portal are retained by the authors and/or other copyright owners and it is a condition of accessing publications that users recognise and abide by the legal requirements associated with these rights.

- Users may download and print one copy of any publication from the public portal for the purpose of private study or research.

- You may not further distribute the material or use it for any profit-making activity or commercial gain

If the publication is distributed under the terms of Article 25fa of the Dutch Copyright Act, indicated by the "Taverne" license above, please 


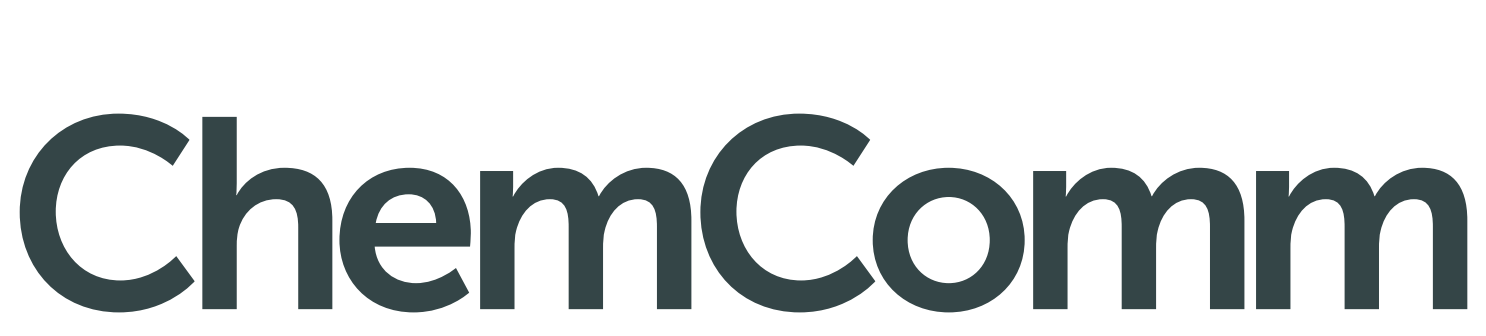

Chemical Communications

www.rsc.org/chemcomm

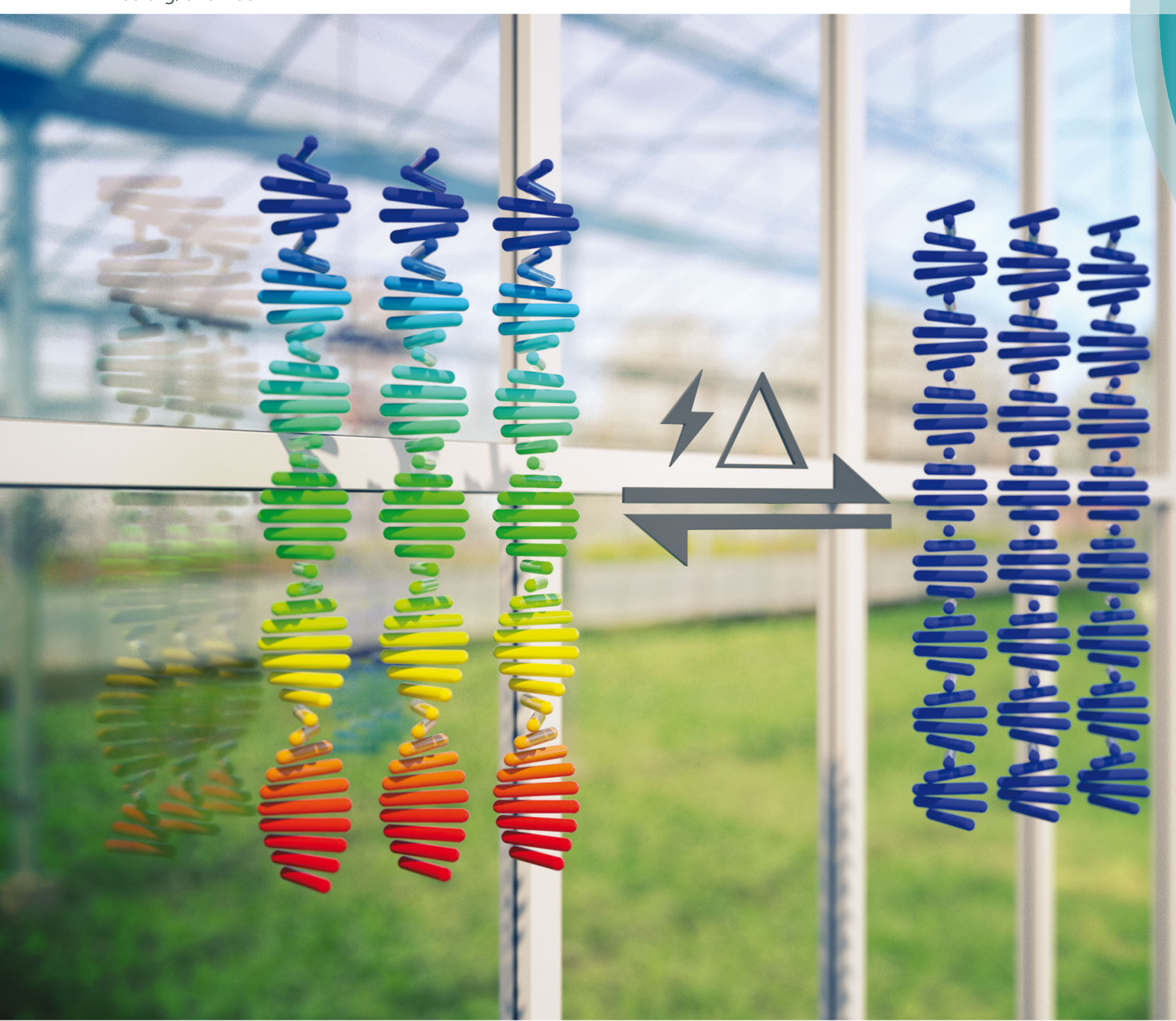

ISSN 1359-7345

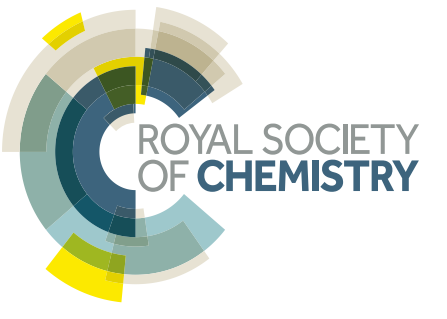

\section{COMMUNICATION}

Michael G. Debije, Albertus P. H. J. Schenning et al.

Dual electrically and thermally responsive broadband reflectors based

on polymer network stabilized chiral nematic liquid crystals: the role of crosslink density

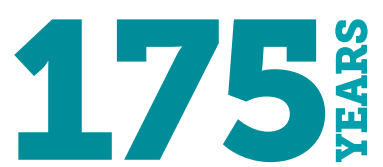




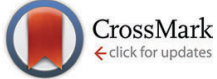

Cite this: Chem. Commun., 2016, 52, 10109

Received 6th June 2016 Accepted 23rd June 2016

DOI: $10.1039 / c 6 c c 04721 a$

www.rsc.org/chemcomm

\section{Dual electrically and thermally responsive broadband reflectors based on polymer network stabilized chiral nematic liquid crystals: the role of crosslink density $\dagger$}

\author{
Hitesh Khandelwal, ${ }^{a b}$ Gilles H. Timmermans, ${ }^{a}$ Michael G. Debije*a and \\ Albertus P. H. J. Schenning ${ }^{\star a c}$
}

\begin{abstract}
A broadband reflector based on a polymer stabilized chiral nematic liquid crystal has been fabricated. The reflection bandwidth can be manually controlled by an electric field and autonomously by temperature.
\end{abstract}

Stimuli-responsive photonic reflectors are the subject of widespread research. ${ }^{1,2}$ In such systems the reflection and transmission of light can be altered by exposure to stimuli including temperature, ${ }^{3}$ light, ${ }^{4-8}$ electricity, ${ }^{9}$ mechanical stress ${ }^{10}$ or chemicals. ${ }^{11}$ This makes these reflectors interesting for a variety of applications ranging from battery-free optical sensors to smart windows for energy management. ${ }^{12-16}$ For certain applications, however, it would be desirable to fabricate materials in which the reflection properties can be adjusted manually depending on user needs or autonomously upon environmental changes. Such dual responsive photonic reflectors have been rarely reported.

Self-organised chiral nematic (cholesteric) liquid crystals (Ch-LCs) are well-known responsive photonic reflectors. ${ }^{17} \mathrm{Ch}-\mathrm{LCs}$ are able to reflect light due to their helical structure and the colour of the reflected light depends on the helical pitch. The bandwidth $(\Delta \lambda)$ of the reflected light depends on birefringence $(\Delta n)$ of the nematic LC host and concentration and helical twisting power (HTP) of the chiral dopants. Generally, the bandwidth is limited to between $30 \mathrm{~nm}$ to $120 \mathrm{~nm}$, depending on the wavelength of the reflection notch. Ch-LC narrowband reflectors have been reported which can broaden their bandwidth in presence of stimuli including electric fields, ${ }^{18-20}$ temperature, ${ }^{21}$ and light. ${ }^{22}$ Few dual responsive narrowband reflectors which change their reflection position have been shown in the literature. ${ }^{23-25}$ Recently, Lu et al.

\footnotetext{
${ }^{a}$ Functional Organic Materials and Devices, Department of Chemical Engineering and Chemistry, Eindhoven University of Technology, Den Dolech 2, 5600 MB Eindhoven, The Netherlands. E-mail: A.P.H.J.Schenning@tue.nl, m.g.debije@tue.nl

${ }^{b}$ Dutch Polymer Institute (DPI), P.O. Box 902, 5600 AX Eindhoven, The Netherlands ${ }^{c}$ Institute for Complex Molecular Systems (ICMS),

Eindhoven University of Technology, 5600 MB Eindhoven, The Netherlands

$\dagger$ Electronic supplementary information (ESI) available. See DOI: 10.1039/c6cc04721a
}

have shown that the bandwidth of a broadband ionic polymer reflector can be adjusted by applying both DC electric fields and temperature. ${ }^{26}$ Diffusion of the chiral ionic polymer in presence of stimuli was used to create such a dual responsive broadband reflector.

Recently, we fabricated a broadband infrared reflector using a flexible polymer stabilized Ch-LC that can be switched from a broadband reflective (planar) state to a transparent (homeotropic) state by applying an AC electric field. ${ }^{27}$ We now report a dual responsive broadband reflector $(\Delta \lambda=620 \mathrm{~nm})$ using a similar method. We show that using a specific polymer crosslink density a broadband reflector can be fabricated whose reflection bandwidth can be reduced by more than $500 \mathrm{~nm}$ upon application of both an AC electric field as well as exposure to elevated temperature. The polymer network was used to create the broadband reflector and stabilize the planar orientation of the nonreactive LC component. ${ }^{28,29}$ It is shown that the crosslink density is crucial for making dual responsive broadband reflectors.

For the fabrication of our dual responsive bandwidth tunable broadband reflector, we have used a similar chemical composition reported earlier, ${ }^{27}$ but with increased concentration of the crosslinker (Fig. 1a). The Ch-LC mixture consists of the nematic liquid crystal E7 (69.5 wt\%), polymerizable chiral dopant CD-267 (13.7 wt\%), non-polymerizable chiral dopant CB-15 (12.1 wt\%), crosslinker RM-82 (2.0 wt\%), photoinitiator Irgacure-651 (1.2 wt\%) and UV absorbing dye Tinuvin-328 (1.5 wt\%). This mixture was used to fill ITO coated glass cells covered with oppositely-rubbed polyimide layers with a cell-gap of $20.4 \mu \mathrm{m}$. This resulted in a reflection notch centered at $\lambda=980 \mathrm{~nm}$ with a bandwidth of $\Delta \lambda=118 \mathrm{~nm}$ (Fig. 1c). The broadband reflector was fabricated by generating a gradient in chiral dopant through photo polymerizing the mixture using low intensity of UV light for one hour at room temperature (Fig. 1b). ${ }^{27,30,31}$ Due to absorption of UV by Tinuvin-328, a gradient of light was created throughout the thickness of the cell, with the intensity of UV light higher at the top side closest to the lamp compared to the bottom side. This causes the reactive mesogens (CD-267 and RM-82) to polymerize faster at the top than at the bottom side of the cell, causing 
(a)

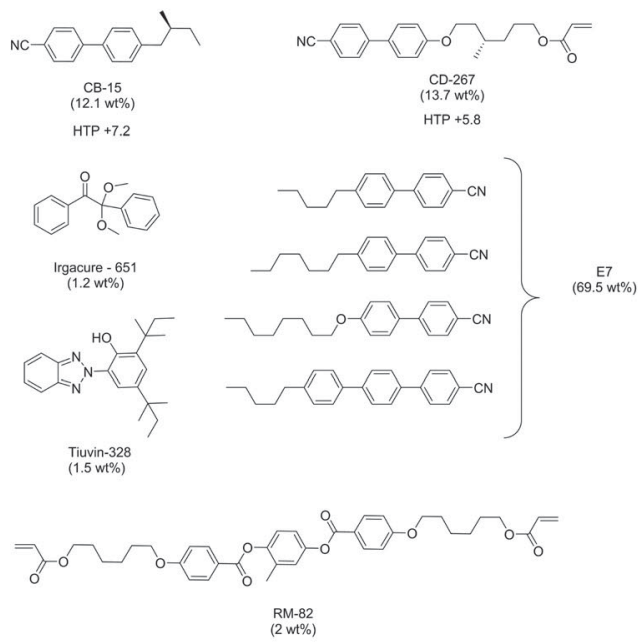

(b)

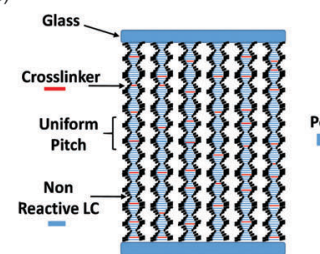

(i)

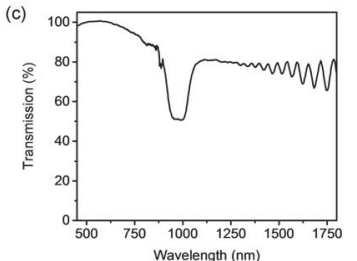

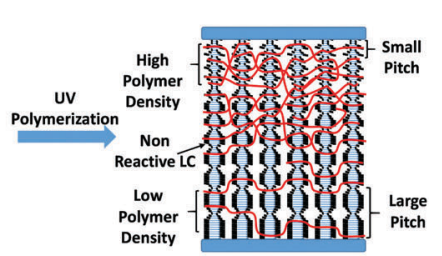

(ii)

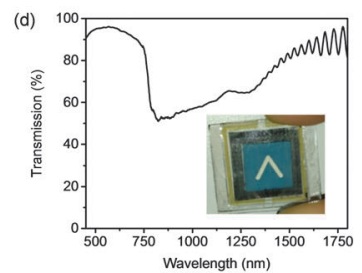

Fig. 1 (a) Molecular structure of the chemicals used for the fabrication of the broadband reflector (b) schematic diagram showing the change in pitch and crosslinking density upon polymerization; transmission spectrum of a cell (c) before and (d) after photopolymerization (inset: photograph of the sample after polymerization).

depletion of these mesogens at the top, which resulted in diffusion of these mesogens from the bottom to the top of the cell. Hence, a concentration gradient of chiral dopant CD-267 and crosslinker RM-82 was created. This also leads to generation of a pitch gradient throughout the thickness of the cell (Fig. 1b) with shorter pitch at the top, resulting in a broadband reflector with a reflection bandwidth of $620 \mathrm{~nm}$ (Fig. 1d).

Having fabricated the broadband reflector, we studied the effect of electric field on the transmission spectrum (Fig. 2a). No significant change in transmission was observed until a threshold voltage $2.2 \mathrm{~V} \mathrm{\mu m}^{-1}$. Upon increasing the voltage from

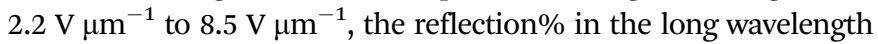
region (around 1000-1400 $\mathrm{nm}$ ) diminishes continuously. At 10.6 $\mathrm{V} \mu \mathrm{m}^{-1}$, the long wavelength reflection disappeared completely, resulting in a narrowband reflector with a reflection bandwidth of $108 \mathrm{~nm}$ centered around $800 \mathrm{~nm}$ (Fig. 2b). Thus, we have fabricated a broadband which can systematically reduce its reflection bandwidth from $620 \mathrm{~nm}$ to $108 \mathrm{~nm}$ on application of voltage from $0 \mathrm{~V} \mu \mathrm{m}^{-1}$ to $10.6 \mathrm{~V} \mu \mathrm{m}^{-1}$ (Fig. 2c). Moreover, the switching from broadband to narrowband can be
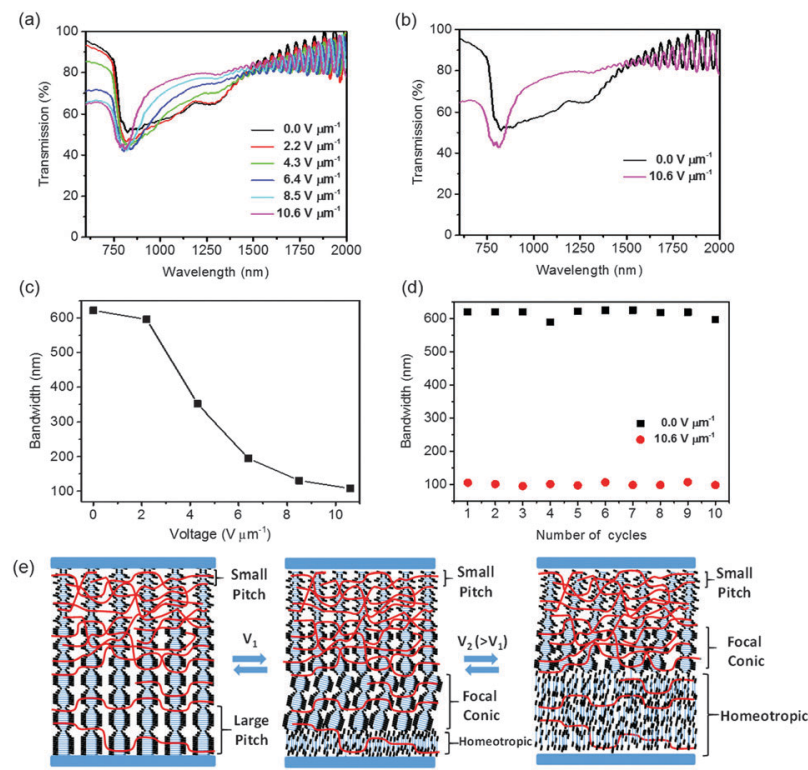

(i)

(ii)

(iii)

Fig. 2 (a) Transmission spectrum of the cell as a function of applied voltage at room temperature; (b) broadband to narrowband switching by applying $10.6 \mathrm{~V} \mathrm{\mu m}^{-1}$; (c) change in the reflection bandwidth with increase in voltage from $0 \mathrm{~V} \mu \mathrm{m}^{-1}$ to $10.6 \mathrm{~V} \mu \mathrm{m}^{-1}$; (d) reversibility data showing the reflection bandwidth during on $\left(0 \mathrm{~V} \mu \mathrm{m}^{-1}\right)$ and off $\left(10.6 \mathrm{~V} \mu \mathrm{m}^{-1}\right)$ states over ten switching cycles; and (e) schematic diagram showing the proposed mechanism for the electrically bandwidth tunable broadband reflector.

done multiple times without significant change in the transmission spectrum (Fig. 2d).

The narrowing in the reflection band on application of electric field can be attributed to a non-uniform distribution of the polymer density. As shown in Fig. 2e(i), the polymer density is higher at the short pitch side (top side) compared to longer pitch side (bottom of the cell) due to the polymerization induced diffusion. On application of $V_{1}=6.4 \mathrm{~V} \mathrm{\mu m}^{-1}$, the Ch-LC with lower polymer density (at the longer pitch side) undergoes homeotropic reorientation, whereas Ch-LC embedded in the region with high polymer density remains unchanged (Fig. 2e(ii)). This causes reduction in the reflection\% in the longer wavelength region whereas the shorter wavelength reflection region remains undisturbed. On further increasing the voltage to $V_{2}=10.6 \mathrm{~V} \mu \mathrm{m}^{-1}$, most of the polymer stabilized Ch-LC undergoes homeotropic reorientation, except in the most highly crosslinked Ch-LC side (shorter pitch length) (Fig. 2e(iii)). This leads to disappearance of the longer wavelength reflection entirely and formation of a narrowband reflector at the shorter reflection edge. It is important to note that upon further increasing the crosslinker concentration (RM-82, $3 \mathrm{wt} \%)$, the modification in the transmission spectrum is no longer as pronounced, as higher crosslinked density requires higher electric fields $\left(>10.6 \mathrm{~V} \mathrm{\mu m}^{-1}\right)$ to attain homeotropic orientation (Fig. S1a, ESI $\dagger$ ). On the other hand, as reported earlier, lowering the crosslinker concentration (RM-82, $0.7 \mathrm{wt} \%$ ) results in the switching of the broad reflection band to a completely transparent state at $8.6 \mathrm{~V} \mu \mathrm{m}^{-1}$, as the entire polymer network is flexible (Fig. S1b, ESI $\dagger$ ). ${ }^{27}$ 

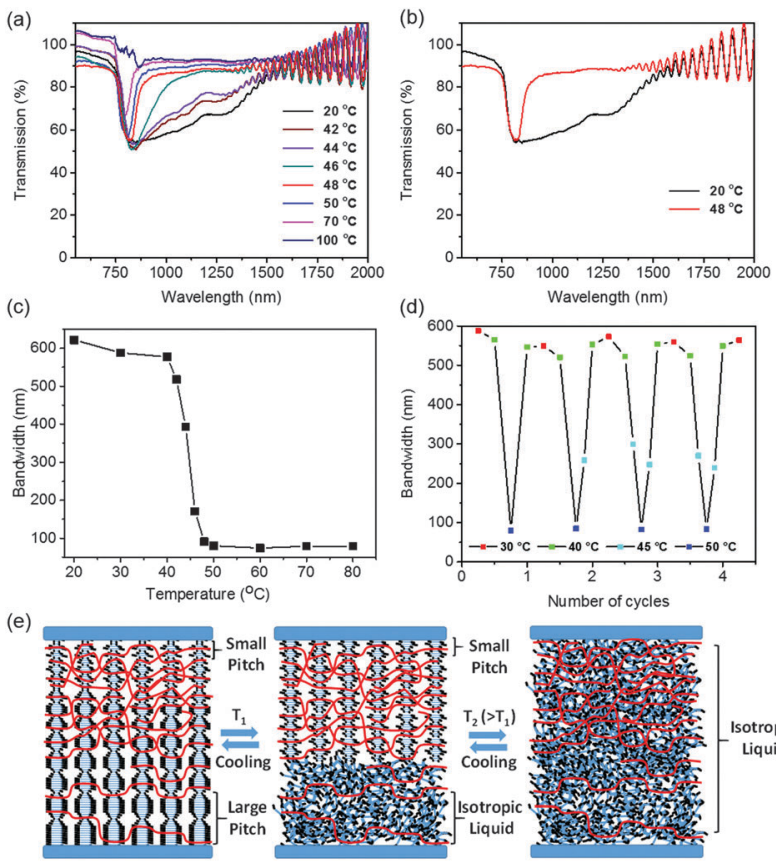

(i)

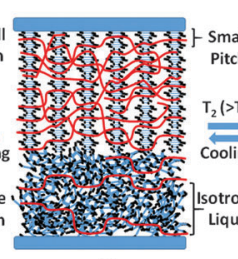

(ii)

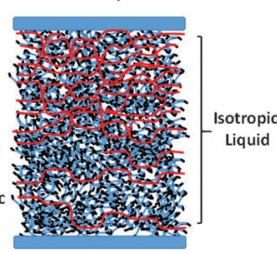

(iii)
Fig. 3 (a) Transmission spectrum of the cell at different temperatures: (b) broadband to narrowband switching at $48{ }^{\circ} \mathrm{C}$; (c) change in the reflection bandwidth on increasing the temperature from $20{ }^{\circ} \mathrm{C}$ and $80{ }^{\circ} \mathrm{C}$; (d) reversibility data showing the reflection bandwidth can be switched multiple times between $30{ }^{\circ} \mathrm{C}$ and $50{ }^{\circ} \mathrm{C}$; and (e) schematic diagram showing the proposed mechanism for thermal bandwidth tunable broadband reflector

We studied the temperature response of the electrically responsive bandwidth tunable broadband Ch-LC reflector as well (Fig. 3a). At room temperature $\left(20{ }^{\circ} \mathrm{C}\right)$, the Ch-LC broadband reflector has a bandwidth of $620 \mathrm{~nm}$. As the temperature increases to $44{ }^{\circ} \mathrm{C}$, the reflection $\%$ at the longer wavelength edge decreases whereas in the shorter wavelength region it remains the same. On increasing the temperature to $46{ }^{\circ} \mathrm{C}$ there is a sudden jump from broadband to narrowband at the shorter wavelength edge; a bandwidth of $170 \mathrm{~nm}$ centered around $820 \mathrm{~nm}$ was observed. On further increasing the temperature, the reflection band continues to narrow: a reflection bandwidth of only $80 \mathrm{~nm}$ is observed at $50{ }^{\circ} \mathrm{C}$. The reflection band completely disappears at $100{ }^{\circ} \mathrm{C}$. On cooling from $100{ }^{\circ} \mathrm{C}$ to room temperature, similar transmission behavior, as seen during heating, was observed (Fig. S2, ESI $\dagger$ ). Interestingly, this bandwidth change from $620 \mathrm{~nm}$ to $\sim 80 \mathrm{~nm}$ on increasing the temperature from $20{ }^{\circ} \mathrm{C}$ to $80{ }^{\circ} \mathrm{C}$ (Fig. 3c) is similar to the electric field response (Fig. 3b versus Fig. 2b). The reflection bandwidth can be changed reversibly from approximately $588 \mathrm{~nm}$ to $80 \mathrm{~nm}$ on increasing the temperature from $30{ }^{\circ} \mathrm{C}$ to $50{ }^{\circ} \mathrm{C}$ without significantly changing in the transmission behavior (Fig. 3d).

In order to better understand the temperature response of the broadband reflector, the effect of temperature on transmission spectrum of the uniformly distributed polymer stabilized narrowband reflector was investigated (Fig. S3, ESI $\dagger$ ). To obtain the uniform distribution of the polymer network in the narrowband reflector, we polymerized the same LC mixture, but this time excluded the UV absorbing dye and photopolymerized using high intensity UV-light so that diffusion of the chiral dopant (CD-267) and crosslinker (RM-82) is minimized. Upon heating up the narrowband reflector, we only observed some narrowing in the reflection band from both the long and short wavelength edges which might be due to decrease in the birefringence of the Ch-LCs. ${ }^{32}$ On further heating the sample, the reflection band completely disappears at $80{ }^{\circ} \mathrm{C}$. These findings reveal that a homogenous polymer network having $2 \mathrm{wt} \%$ crosslinker is able to uniformly stabilize the orientation of the non-polymerized LCs. The effect of change in HTP of CB-15 and CD-267 at elevated temperature can be neglected, ${ }^{33}$ as we did not observe a change in the position of the reflection notch upon heating (Fig. S3, ESI $\dagger$ ). Therefore, for the broadband reflector, the nonuniform distribution of polymer density could be the main reason for narrowing in the reflection band at short wavelength region.

As the temperature response is similar to the electrical response, we propose the following underlying mechanism behind the observed narrowing of bandwidth of the broadband reflector at elevated temperatures (Fig. 3e). At higher temperatures $\left(T_{1}=48{ }^{\circ} \mathrm{C}\right)$, the least crosslinked Ch-LC region (at the bottom of the cell, cross link density $<2 \mathrm{wt} \%)$, becomes isotropic, whereas higher crosslinked region (top of the cell, cross link density $>2 \mathrm{wt} \%$ ) remains in their LC phase (Fig. 3e(ii)). This results in the appearance of a narrowband reflector at the shorter wavelength side with simultaneous disappearance of the long wavelength reflection band. On further increasing the temperature $\left(T_{2}=100{ }^{\circ} \mathrm{C}\right)$, the Ch-LC region with higher polymer density also undergoes phase change into the isotropic state (Fig. 3e(iii)) resulting in the complete disappearance of the reflection band. The non-uniform clearing temperature of the LC mixture throughout the thickness of the cell could be due to the difference in crosslink density between the top and bottom of the cell. The LC with high polymer network density provides stronger anchoring to the non-reactive LC, causing an increase in the local isotropic transition temperature. This was confirmed with a narrowband reflector with 3 wt\% crosslinker which was found to have a higher isotropic transition temperature compared to the narrowband reflector with $2 \mathrm{wt} \%$ crosslinker (Fig. S4, ESI $\dagger$ ).

In conclusion, we have fabricated a dual responsive broadband cholesteric reflector which can reduce its reflection bandwidth by more than $500 \mathrm{~nm}$ either upon application of an electrical field or by changes in temperature. A novel method has been developed by optimizing the concentration of the crosslinker where the reflection bandwidth of the broadband can be systematically reduced. Such findings can be used with other polymer stabilized liquid crystals to prepare dual responsive tunable photonic materials. The unprecedented manual or autonomous change in the infrared reflection makes these reflectors interesting for application in heat controlling smart windows to maintain more comfortable climates within automobiles and buildings and improved growing conditions within greenhouses. ${ }^{34}$ 
This research forms part of the research program of the Dutch Polymer Institute (DPI), project 764.

\section{Notes and references}

1 Q. Li, Intelligent Stimuli-Responsive Materials, John Wiley \& Sons, Inc., 2013.

2 Y. Yin, H. J. Schneider and M. Shahinpoor, Responsive photonic nanostructures smart nanoscale optical materials, Royal Society of Chemistry, Cambridge, 2013.

3 J. D. Debord and L. A. Lyon, J. Phys. Chem. B, 2000, 104, 6327.

4 V. Shibaev, A. Bobrovsky and N. Boiko, J. Photochem. Photobiol., A, 2003, 155, 3.

5 Z. Zheng, Y. Li, H. K. Bisoyi, L. Wang, T. J. Bunning and Q. Li, Nature, 2016, 531, 352.

6 H. K. Bisoyi and Q. Li, Acc. Chem. Res., 2014, 47, 3184.

7 J. Ma, Y. Li, T. White, A. Urbas and Q. Li, Chem. Commun., 2010, 46, 3463.

8 L. Wang, K. G. Gutierrez-Cuevas, H. K. Bisoyi, J. Xiang, G. Singh, R. S. Zola, S. Kumar, O. D. Lavrentovich, A. Urbas and Q. Li, Chem. Commun., 2015, 51, 15039.

9 L. Nucara, F. Greco and V. Mattoli, J. Mater. Chem. C, 2015, 3, 8449. 10 H. Fudouzi and T. Sawada, Langmuir, 2006, 22, 1365.

11 W. Hong, X. Hu, B. Zhao, F. Zhang and D. Zhang, Adv. Mater., 2010, 22, 5043 .

12 D. J. Broer, C. M. W. Bastiaansen, M. G. Debije and A. P. H. J. Schenning, Angew. Chem., Int. Ed., 2012, 51, 7102.

13 D. J. Mulder, A. Schenning and C. Bastiaansen, J. Mater. Chem. C, 2014, 2, 6695.

14 M. Moirangthem, R. Arts, M. Merkx and A. P. H. J. Schenning, Adv. Funct. Mater., 2016, 26, 1154.
15 H. Khandelwal, R. C. G. M. Loonen, J. L. M. Hensen, A. P. H. J. Schenning and M. G. Debije, J. Mater. Chem. A, 2014, 2, 14622.

16 L. Wang and Q. Li, Adv. Funct. Mater., 2016, 26, 10.

17 M. Mitov, Adv. Mater., 2012, 24, 6260.

18 K. M. Lee, V. P. Tondiglia, M. E. McConney, L. V. Natarajan, T. J. Bunning and T. J. White, ACS Photonics, 2014, 1, 1033.

19 H. Khandelwal, M. Debije, T. White and A. P. H. J. Schenning, J. Mater. Chem. A, 2016, 4, 6064.

20 W. Hu, H. Zhao, L. Song, Z. Yang, H. Cao, Z. Cheng, Q. Liu and H. Yang, Adv. Mater., 2010, 22, 468.

21 H. Yang, K. Mishima, K. Matsuyama, K.-I. Hayashi, H. Kikuchi and T. Kajiyama, Appl. Phys. Lett., 2003, 82, 2407.

22 T. J. White, A. S. Freer, N. V. Tabiryan and T. J. Bunning, J. Appl. Phys., 2010, 107, 073110.

23 J. E. Stumpel, D. J. Broer and A. P. H. J. Schenning, RSC Adv., 2015, $5,94650$.

24 M. Mathews, R. S. Zola, D. Yang and Q. Li, J. Mater. Chem., 2011, 21, 2098.

25 F. J. Chen, J. B. Guo, O. Y. Jin and J. Wei, Chinese J. Polym. Sci., 2013, $31,630$.

26 H. Lu, J. Hu, Y. Chu, W. Xu, L. Qiu, X. Wang, G. Zhang, J. Hu and J. Yang, J. Mater. Chem. C, 2015, 3, 5406.

27 H. Khandelwal, R. C. G. M. Loonen, J. L. M. Hensen, M. G. Debije and A. P. H. J. Schenning, Sci. Rep., 2015, 5, 11773.

28 I. Dierking, Adv. Mater., 2000, 12, 167.

29 M. Mitov, E. Nouvet and N. Dessaud, Eur. Phys. J. E: Soft Matter Biol. Phys., 2004, 15, 413.

30 R. A. M. Hikmet and H. Kemperman, Nature, 1998, 392, 476.

31 D. J. Broer, J. Lub and G. N. Mol, Nature, 1995, 378, 467.

32 J. Li, S. Gauza and S. T. Wu, J. Appl. Phys., 2004, 96, 19.

33 R. A. M. Hikmet and H. Kemperman, Liq. Cryst., 1999, 26, 1645.

34 Nanomaterials for Sustainable Energy, ed. Q. Li, Springer, 2016. 